\title{
Young Prisoners' Experiences of the Positive Factors of Small Group Teaching during Their Basic Education - Toward the Pedagogy of Preventing Social Exclusion
}

\author{
Tanja Äärelä \\ Faculty of Education, University of Lapland \\ PO Box 122, 96101 Rovaniemi, Finland \\ E-mail: Tanja.Aarela@rovaniemi.fi \\ Kaarina Määttä \\ Faculty of Education, University of Lapland \\ PO Box 122, 96101 Rovaniemi, Finland \\ E-mail: Kaarina.Maatta@ulapland.fi \\ Satu Uusiautti (Corresponding Author) \\ Faculty of Education, University of Lapland \\ PO Box 122, 96101 Rovaniemi, Finland \\ E-mail: satu_uusiautti@hotmail.com
}

Received: August 6, 2014

Accepted: Oct. 17, 2014 Published: November 1, 2014

doi:10.5296/jse.v4i4.6452

URL: http://dx.doi.org/10.5296/jse.v4i4.6452

\begin{abstract}
In this study, young prisoners' school memories were studied. The purpose of the study was to find out if small group teaching could help children in danger of exclusion. The following research questions were set for this study: (1) What was the transition process to small group teaching like according to the young prisoners' descriptions?; and (2) How did the small group teaching arrangement support school work according to the young prisoners' descriptions? Narratives of their school time from twenty-nine young prisoners, aged 17-21,
\end{abstract}




\section{Macrothink}

from two prisons in northern Finland were obtained through interviews. Small group teaching had represented a change toward better school satisfaction and well-being to all those who had been moved to such a group. The young prisoners' interviews pointed out several elements that make a successful small group teaching. These positively-perceived factors were communality and peer group, flexible and functional study methods, and caring, encouraging teachers. We combine the elements here as the pedagogy of preventing social exclusion (PPSE), which is introduced as the conclusion of this study.

Keywords: Juvenile delinquency, Young prisoner, Small group teaching, Exclusion, Pedagogy, Narrative research 


\section{Introduction}

Imprisonment can be seen as the extreme of exclusion process. Exclusion from school is one of the core elements increasing and activating the exclusion process, and according to previous studies (Garrison, 2006; Wilson, Malcolm, Edward, \& Davidson, 2008), youth ending up committing crimes have experienced injustice at school and alienated themselves from the school system and peer groups. Could dropping out from school and related exclusion development be prevented?

When analyzing the role of dropping out in criminal behavior, Sutherland (2011) tried to answer the question whether youth dropped out because they committed crimes or committed crimes because they were not at school. In Sutherland's opinion, it is not possible to say that school experiences make youth commit crimes but negative school experiences increase the risk of vulnerable young people drifting into criminal behaviors. Sutherland (2011) presents a review of education-created risk factors that are related to juvenile delinquency. The illustration includes seven categories that are

(1) inadequate transition to school, and from primary to secondary school,

(2) an unhealthy school climate,

(3) schools' contribution to academic failure,

(4) anti-social peer relationships formed at school,

(5) negative relationships between students and school personnel,

(6) mistreatment by school personnel, and

(7) school policy abuse (Sutherland, 2011, pp. 52-55).

In this study, young prisoners reminisced their school years. We consider imprisonment as the most extreme manifestation of exclusion. However, the starting point of the study was a thought that even these youngsters must have had some positive experiences from school and not just negative. Although many of them are dropouts, they presumably have had good moments or positive events at school. When digging up these experiences through interviews, especially transition to small-group teaching and studying as a member of a small group became highlighted. In this study, these positive experiences are further analyzed. These questions started to interest us after Dr. Äärelä had compiled her doctoral thesis on young prisoners’ experiences (see Äärelä, 2012). She also works as a special education teacher at a psychiatric unit of hospital school, and thus has to think about the skewed school paths and prevention of them every day at work.

In this study, we leaned on the opportunity to prevent children's unhealthy development through education and schooling. Positive experiences can function as buffers against negative ones. This idea will be further discussed in the conclusion.

\section{The Concepts of Dropping out from School and Exclusion}

In the Finnish school system, elementary education refers to grades from 1 to 6 and secondary education to grades from 7 to 9. Education after basic education (compulsory education) is called upper secondary education. A "school drop-out" is a concept referring to youth, who do not graduate from basic education. When defined wider, drop-outs cover also 
those who do not start or quit upper secondary education (Shannon \& Bylsma, 2003).

It is questionable to name any separate reason that leads to someone dropping out from school; but it is possible to name related risk factors at individual and communal levels (Christenson \& Thurlow, 2004; Dynarski \& Gleason, 2002). Multiple problems typify individuals who drop out from schools, while at the communal level the growth environment appears significant (Terry, 2008). Those children and youth, who do not receive adequate support from home or close people to their school work, are at the greatest risk of dropping out from basic education. Likewise, children with difficult social background are in danger of dropping out. Economic scarcity of a family can also expedite the exclusion process (Blondal \& Adalbjarnardottir, 2009; Horgan, 2009; Reich, 2006; Teodorovic, 2012). Poor school achievements predict dropping out to some extent (Battin-Pearson et al., 2000). In addition, children with behavioral problems have been noted to drop out more easily from school than children behaving normally (Archambault, Janosz, Morizot, \& Pagani, 2009; Christenson \& Thurlow, 2004; Jimerson, Egeland, Sroufe, \& Carlson, 2000; Miech et al., 1999; Staff \& Kreager, 2008).

From the ecological perspective, the school drop-outs emerge when the expectations of the school, requirements of the environment, and students' abilities do not converge. Therefore, exclusion is not just an individual-level problem but a wider, system-level problem that is a part of a bigger entity, social reality, and demands of school that students are capable of meeting (Brown \& Rodríguez, 2009; Knesting \& Waldron, 2006).

In Finland, about $10 \%$ of youth drop out during the transition from basic education to upper secondary education, when also those who quit school during the fall semester are included in the number. This phase has also been called the black hole of the Finnish student counseling, because at that point, no one really has the counseling responsibility (Pirttiniemi, 2005). More and more attention has been now paid to the intensive support and multi-professional co-operation during the transition from basic education to upper secondary education (see e.g., Kuronen, 2010; see also Deuchar, 2009).

Finland's situation is, however, better than in many other countries in European Union (Dearden, Emmerson, Frayne, \& Meghir, 2005). In the United States of America, the number of drop-outs has been alarmingly high for a long time, but when compared to Finland, USA has much bigger racial and regional differences too (Ferri \& Connor, 2005; Lareau \& McNamara Horvat, 1999; Orfield, Losen, Wald, \& Swanson, 2004). A rough estimation is that over one million youngsters per year, approximately $3.5 \%$, quit school (Chapman, Laird, \& KewalRamani, 2010). This means concretely that one schoolchild drops out from school every ninth second (Christenson \& Thurlow, 2004). Only about $10 \%$ of American drop-outs return to school (Vitaro, Larocque, Janosz, \& Tremblay, 2001; Wilkins, 2008).

Despite the differences between national school systems, the risk factors of dropping out from school seem quite similar at the individual level (cf. e.g., Brown \& Rodríguez, 2009; Jonker, 2006; Sutherland, 2011). Those youth who drop out are in bigger risk of committing illegal actions, being excluded from society, and go to prison than those who have been well integrated in education (Vitaro et al., 2001). 


\section{Small Group Teaching}

Small group teaching means basically teaching of a class with fewer students making more individualized teaching possible when compared to normal class sizes (Fryer-Edwards, Arnold, Baile, Tulsky, Petracca, \& Back, 2006). Small group teaching also attempts to guarantee as few changes as possible in the group and in teaching arrangements during school days.

The significance of the group size to students' learning and development is a widely discussed topic (Fischer, Bol, Pribesh, \& Nunnery, 2013). According to some viewpoints, the learning atmosphere in the classroom is more relevant than the number of students in the classroom (Adelman \& Taylor, 2006; Dorman, 2001). However, the group size seems to matter especially at the beginning of education (Rudasill, 2011). Moreover, students with special needs and particularly boys seem to benefit from a smaller student group making it possible for them to practice, for example, social skills more intensively (Denham, Hatfield, Smethurst, Tan, \& Tribe, 2006). A Norwegian review revealed that the positive influence is at its greatest when the group size is 20 students or less (Sarras, 2011). Research on class sizes will continue (Arias \& Walker, 2004), and how the size of a student group contributes to students' learning results depends on many other factors within the classroom and at school as well (Borland, Howsen, \& Trawick, 2005; Pedder, 2006).

In the United States, discussion over class sizes has been focused on the cost-effectiveness, and therefore, class sizes are big (Blatchford, Russell, Bassett, Brown, \& Martin, 2007). Likewise, a fourth of British 7-11-year-old children study in classes of over 31 students, which means that the individualized attention given to each student remains minimal (Blatchford et al., 2007). In Finland, municipalities arrange teaching and the recommendation given to them is that each teaching group should not have more than 20-25 students (Ministry of Education and Culture, 2012; 2014).

\section{Method}

The purpose of this study is to describe the significance of small group teaching in the light of young prisoners' school experiences and school memories. The study focused on the transition to a small group teaching and on the young prisoners' perceptions of the benefits and problems of small group teaching. The fundamental goal is to analyze how teaching could be developed to better prevent dropping out from school.

The following research questions were set for this study:

(1) What was the transition process to small group teaching like according to the young prisoners' descriptions?

(2) How did the small group teaching arrangement support school work according to the young prisoners' descriptions?

The results include descriptions of the narratives of their school time from twenty-nine young prisoners, aged 17-21, from two prisons in northern Finland. The participants were selected leaning on the criterion for a young prisoner (age of younger than 21 years), but as the 
number of young prisoners was so small, also 21-year-old prisoners were included in the study. Most of the prisoners were men but also two women participated in the study. The majority of the participants did not have earlier criminal background but, for example, one of the prisoners was sentenced already six times despite the young age. The third of the prisoners had been sentenced due to several crimes, which is typical of juvenile delinquency. The participants' backgrounds, in other words their living environments, seemed to be mostly fragile and unstable but three of them also came from socio-economically high status families. About a half of the prisoners had had psychiatric treatment periods of different length as well as various, even repetitious periods of placement outside home.

This study employed the narrative research approach. Narratives have become a central method of qualitative research, and this trend has been even referred to as a narrative turn (Riessman, 2008). Narrative research is based on social constructionism (Burr, 1995; Gergen, 2009). The fundamental idea is that people construct their knowledge and identities in social interaction through language and narratives. In this study, young prisoners' narratives about their school years formed the research data. Narratives were acquired with free-form interviews that resembled the narrative interview method (see Atkinson, 2007; Cortazzi \& Jin, 2006; Kvale, 2002; 2007; Watson, 2006; Wells, 2011). The youngsters could decide what they would talk about and thus focus on issues they found important and significant. In other words, the researcher did not present specified questions. Narrative research made is possible to reach the research participants' authentic voices (Abbott, 2008; Chase, 2005). The narratives were analyzed through qualitative content analysis and the narrative research approach applying Polkinghorne's (1995) and Lieblich, Tuval-Mashiach and Zilber's (1998) analyzing models. In the analysis of narratives, the most significant categories representing the teachers' influence over attending school and the teachers' behavior were formed and are here represented as the results.

When reporting the results, excerpts from interviews are added in the results section. They are kept totally anonymous, and even the gender of the participant is withdrawn. However, the quotations are important as they give voice to the prisoners and show the reader how the researcher has interpreted the narratives. When translating the interview quotations, we have tried to be as literal as possible to the language the young prisoners used. However, it was not possible to include the dialects the prisoners used - still, the excerpts include profanities and other expressions typical of their language.

\section{Results}

The young prisoners' school memories were mainly very problem-centered. Failures and injustices faced at school were strongly evinced in their stories. The most apparent feelings were indifference, disappointment, and, along school years, increasing disgust and hatred toward the school and teachers. One positive factor was in common to these young prisoners: transition to and studies in small group teaching. These positive experiences had to be interpreted from the young prisoners' expressions: what was not described negatively, had to be regarded as positive:

Time in elementary education was, at least, not crappy. 
Of these 29 young prisoners, 21 had been moved in small group teaching during their basic education. Most of them had been, at first, against the transition, but quite soon all of them had noticed that it had made school more tolerable. All of them finished compulsory education, although some had to repeat classes. Of those eight young prisoners, who had not participated in small group teaching, five had had only about ten students in their classes which is the maximum number of students in small group teaching anyway. Of those three who had stayed in a bigger teaching group, one had quit school and two had such poor final reports that they were not accepted in vocational education where they had applied.

It is worth noticing that transition to small group education does not only happen based on a student's characteristics. Other reasons can include, for example, school resources, school culture, and wider-scale expediency consideration. This study describes the young prisoners' own interpretations of the factors for which they were moved to small group teaching and how studying in small group teaching appeared to them.

\subsection{Defying the Limits, Inappropriate Behavior, and Unauthorized Absenteeism}

Many young prisoners described how they had not adjusted to the rules and structured everyday life at school. Therefore, grouped and goal-oriented school work had been especially challenging to them. Some of the prisoners had found it very difficult to, for example, follow the given schedules still in prison. However, the prison had set the limits that no one else had been able to set to these youth. One of the youngsters told how he did not want to wake for breakfast in prison at first, but described how hunger had made him wake eventually:

It was probably the fucking first time when I obeyed the orders, the first time when I did not have the choice. So here I have almost lost my mind because you don't have any options, you just have to do what you're told to do or you suffer... When I think about the time at school, I see that they didn't have any chances to deal with me because I have never understood why there are rules. Rules are to be broken, in my opinion... It was easier in that small group, though. I wasn't that impossible, I tolerated it, however, better. It wasn't just that stupid carping.

Several young prisoners described the same kind of attitude about breaking the rules. As the school years went by, their conscious, intentional, and target-oriented disturbance during teaching and them bullying the teachers became a salient part of their school days (see also De Wet, 2010; Dzuka \& Dalbert, 2007). Noteworthy, the young prisoners' anti-school action aiming at disturbing teachers' work had not focused on all teachers. Clearly, they had bullied just certain teachers based on their experiences and impressions of the teachers (see also Liew, Chen, \& Hughes, 2010). Some teachers' lessons had had a generally positive atmosphere among students and the teacher. When the group had then moved to another lesson, from one teacher to another, the situation could turn into downright impossible.

Teachers who were more relaxed and understanding; I didn't bully them. They realized that everyone cannot be interested in everything, and thus didn't stalk you and complain all the time. I can't say that those [who I bullied] would have been bad at their work, but ones, hard 
to say, whose personalities didn't appeal to me, starchy... I was just scoring points, nothing personal I guess but general fucking and disturbance.

A few of the young prisoners described how they had tried to do their school work in the large group without disturbing the teaching or other students. They had understood that misbehaving was not going to benefit them. This unmotivated but not disturbing presence at school had been interpreted as passiveness, which had also caused trouble. Regardless of their efforts, some of the young prisoners had been in trouble with their teachers constantly, for example, due to neglecting homework. They had not done their homework or done them inadequately. They had hated homework, but had been doing it. This had not, however, satisfied their teachers. The young prisoners had experienced the demands as unreasonable and unfair. They had been complained about the same issues day after day. These teachers and school subjects had started to seem more and more meaningless, and constant railing about homework had made them avoid confrontations with teachers and skip lessons (cf. also Split, Hughes, Wu, \& Kwok, 2012).

I did the homework usually. Not always that well, but that's not so dangerous because I'm the one not learning so well those things... I even did those note book tasks, although they were overly annoying. I hated them the most. I still did. Yes, it started to get to me, especially when that math teacher yelled me about some width of marginal in my note book. How horrible, the fucking marginal is missing. Three squares, it is three squares [shrilling and imitating the teacher, wagging the forefinger]. What can you do, it starts to get to you. Or if you don't have your ruler there and you do that three-square marginal without it, as straight as possible however, and then that's the problem. No, no, it's impossible. Why do they have to pounce on these things and always complain? ... So, I didn't go to these lessons... I knew that it was me who would suffer the most of it, but at that point, there was nothing that I could do. When young, your thinking is so mixed up. And you are so completely pissed off. And when I seriously tried to do my best, and still they would pounce on these issues. I have fucking something else to think about than just squares in marginal and lines made with a ruler. I had bigger problems, but teachers didn't, uh?

Education did not seem to reach these young students, and due to their misbehavior and high absenteeism that were described the prisoners, the school system had tried to fix these issues with transitions to small group teaching. Next, we will introduce findings related to the transition and preceding problems.

\subsection{The Deep Roots of Problem Behavior}

In the interview data, transitions to small group teaching and preceding problem behavior harked back to childhood homes in many young prisoners (see also Sharabi, Levi, \& Margalot, 2012). School children bespeak of the culture and habits of their home environment. Among these youngsters, life at home had not been very structured or regular (Swanson et al., 2014). For some of them, underprivileged status originated even over generations before them.

Many prisoners hoped that schools would pay attention to children's life situations more 
holistically. Some of them had realized already at school that their homes were different from most of the other students' homes. One told about her mother's death when he had went from elementary to secondary school and his father had started to use more and more alcohol and was not able to take care of his child's basic needs.

He would sleep wherever, even at daytime, pass out in other words. He had this hard time then.

The young prisoner described how he had tried to go to school but still could not handle it, because he was just reprimanded even though he thought he had worked so hard (see also Busch \& Kimble, 2001; Holland, 2008). The prisoner in question had started to use substances and alienated himself. When this student had felt depressed enough, he had quit school, although deep down, he did not want to do that:

It was just so fucking bad and difficult to be there that I didn't want to be there at all. I felt anxiety really. It wasn't easy for me at all, although in my opinion, I did my best... I didn't disturb anyone ever, I wasn't mean or anything, I certainly didn't harm anyone... I wasn't a good decision to quit, I knew it at once, that my state didn't get better by quitting, it was just bad in a different way. I knew I did wrong, I wouldn't want to do wrong, but I just couldn't do right. Or be there, at school. There was something so, I can't say, how it was. Or what I told earlier, I think it was just so unfair in many ways.

Education professionals should be prepared to notice the families' interactional readiness to collaboration when it comes to children in danger of exclusion. It means that educators need to pay attention to students' home conditions and the ways parents interact with their children. Not all parents are interested and ready to be involved in their children's school work, nor are they interested in schooling and education. Therefore, teachers cannot assume that every parent is willing to extensive collaboration, but by familiarizing with students' backgrounds individualized support could be established. This might be the only way of helping the student. Just surviving alive from school does not help students to move to upper secondary education, as one young prisoner described:

I'm happy that I survived in the first place. Fuck I was so troubled sometimes that I thought of killing myself, take pills or jump under a truck or something. Sometimes I seriously thought about that when walking to school. I just felt like going somewhere else. Actually only thinking about what it would do to my parents made me not to jump and kill myself. You can't describe by words how ultimate the feeling there was, the dark cloud around me, and nothing goes right. I was an alien there... I haven't applied to anywhere [school] because I haven't wanted to continue that suffering.

\subsection{Small Group Teaching Provided Support for School Going}

Transition to small group teaching primarily increased the young prisoners' motivation to finish compulsory education. Later on, they appeared happy that they had completed it. Most of the young prisoners who had been moved to small group teaching believed that they had quit school without the transition. 
If this group had not existed, I probably would not have gone to secondary education.

According to the young prisoners' perceptions, the most important factors in better contentment with school were the communal atmosphere of the small group, flexible and functional study methods, as well as encouraging and understanding teachers. We will introduce these factors of small group teaching in detail as follows.

\subsubsection{Finding a Peer Group, Communality as an Empowering Factor}

Friends had big roles in many young prisoners' narratives about school (see also Farmer, McAuliffe Lines, \& Hamm, 2011). Instead of describing deep friendships, peers were people with whom the young prisoners had spent time during breaks. During lessons, many young prisoners were trying to amuse their classmates. In a bigger group, this had not succeeded so well. The young had considered themselves different from others, because they had not been interested in school subjects, and persevering at school work had felt strange and frustrating.

In small group teaching, the aforementioned attitudes had changed. Students selected in small group teaching had had somewhat similar attitudes to school. None of the young prisoners felt that they had differed from others in the small group, as was the case in general education. Noteworthy, many of them described how they now had peace to learn and study. Moreover, they had followed the rules better in small group teaching than in general education. Although students' activities were not always aligned with the school's goals, the young prisoners had liked school more and their school days had become more suited to them in many ways (see also Hughes \& Chen, 2011).

It was good because you could familiarize with all classmates because there were fewer of them. Surely, it had flaws too, but let's not get into that right now. [laughs when asked to tell more about the negative sides] Well, ok, because you insist. [laughs] It's no good if all the rascals are gathered in the same group. It will cause some trouble too, for sure. I guess you know it, right. Things happen wherever we go.

The aforementioned prisoner refers to the basics of inclusion-segregation discussion: on the one hand, students in a small group received more individualized guidance and support, and therefore, their learning goals can be better achieved. On the other hand, transition to a small group defines students' social environment with the people selected in the group. For example, while an aggressive youngster can be deplored in general education groups, he or she can be even admired by others in a group of other aggressive students. This was manifested in the young prisoners' descriptions of how they showed their fighting skills in a small group (cf., Gardner \& Steinberg, 2005; Weerman, 2003).

However, as quitting school is the best separate indicator of the danger of exclusion, transition to small group teaching had made the young prisoners go to school more often and regularly, and prevented them from dropping out from school.

\subsubsection{More Sensible Teaching Methods}

Many young prisoners' school achievements had improved in small group teaching already because of the fact that, when their absenteeism decreased, they also started to have actual 
records from school work. Many of them had been able to raise their Fs into D or better. Two of the young prisoners had gotten a scholarship during their years in small group teaching: one for good behavior and one for improved school achievements. Some youngsters described how they had been doing homework for the first time during their school paths. Most of the transitions had happened during the sixth and seventh grades, which means that they had spent many years at school before the more radical forms of support were realized (see also Williford, Maier, Downer, Pianta, \& Howes, 2013).

Every student was noticed individually in small group teaching. This was perceived as extremely important and positive. The young prisoners had felt that they were cared for even though they did not enjoy school work very much (see also Äärelä, Uusiautti, \& Määttä, 2014). The teacher had organized group activities and guided each student in a way that suited the student best (see also Liew, Chen, \& Hughes, 2010). The next data excerpt illustrates the reward system that was possible to use in a small student group. The system had been very important and agreeable to the young prisoners:

Well the coffee maker! You just could not switch it on before everyone had done their tasks. So, it was a sort of group discipline, but worked for us. We would always load it beforehand during breaks, and then we would be nagging a lot if someone couldn't finish his or her tasks. Not like bullying, but like spurring, in a good spirit... Sometimes, if we were cussing a lot, we were not allowed to switch it on, or if there had been some difficulties or problems.

More functional working methods meant in practice that the youngsters were able to move more freely in the classroom and school premises. Even work with text books was not tied to a desk, in a classroom, or even in the school building. Likewise, their school work had been freer from time control, and in most cases, they had been working as long as they had finished their tasks — sometimes, it could take a while. The young prisoners described that these methods had improved their learning.

Many times we would just take the books and go outside or somewhere else to lie and study. It was just so much nicer than just sit in that fucking stuffy classroom. And for example, when the lesson ended you could leave them there and continue when the bell rang... I found that piecework pleasing, to finish what you started, even if it was sometimes slower. But not to jump from one subject to another all the time and then you'd remember nothing about what the fuck you were supposed to learn and do. I liked that we didn't have to change classrooms all the time and carry the books back and forth.

Some young prisoners analyzed the advantages of small group teaching in relation to its weaknesses (cf. also Chen, Hughes, Liew, \& Kwok, 2010). They discussed the positive sides following it but could also recognize negative influences, as the following data excerpt manifests:

All us rascals in the same group... You do all stupid things, and we would booze together too. Then the school going gets worse for good. You don't study at all, just go and act like fools; it's like that then... Well, I managed to finish school, good in that way, but I don't know if I had coped in the normal education, probably not. 


\subsubsection{Caring Teacherhood Providing Support and Encouragement}

Teacher experiences from the times of small group teaching were considerably more positive than experiences from bigger class sizes. The young prisoners described how, alongside the transition to small group teaching, their everyday life at school had gotten an adult who take care of the smoothness of their school work. Teachers were more relaxed and not pouncing on small issues, like they had in earlier classes. The most evident reason for the positive change seemed to be the intensified support and control that small group teaching provided. Notwithstanding, holistic care and attention were appreciated (see also e.g., Baker, 2006; Noddings, 2005). One small group teacher had picked up students to school from their homes or the village gas station, if the students had forgotten to come to school and the teacher was not informed of a proper reason for absence.

At first, for me it was, that I was absent from school hell a lot, I skipped. Because of that, I ended up in there [small group teaching] because I had not been at school for a day really. I was more interested in being downtown and such. But then the teacher was someone who would pick you up if you didn't go to school but went to the village. You had to go; the teacher threw you in the car saying 'now you boy go to school'. Or if you stayed at home sleeping, the teacher was behind your door and came to collect you 'put your clothes on'. He was a good teacher, and I attended school. We got along fucking well, although at times I felt that he was a dick, but now afterwards, he seems the best teacher I've ever had.

The prisoners remembered that some teachers had the habit of calling to students' homes quite soon in the morning if students did not come to school. Usually, these phone calls had worked. The prisoners explained that, otherwise, they would have just spent the day sleeping. In small group teaching, students were not controlled with punishments any longer but in more appropriate means, through educative discussions and positive attention:

It was noticed and seized at once, if you were absent or did something else... If you had any problem, you would always know who to ask. And sometimes you didn't even have to because they would already tell and take care. We talked about everything, it was not just yelling about detention or something.

Descriptions about small group teaching evinced clearly how important it was for these young prisoners to feel that a teacher cares (see also Äärelä, Uusiautti, \& Määttä, 2014). Indeed, the teacher had been the most significant factor increasing their well-being at school. Teachers who accepted students as they were without expecting too much of them and giving feedback from even the smallest positive accomplishments became accepted and liked in return - and as they were:

One was such a good teacher, because he got us along in this thing. He was irreplaceable to me; I couldn't have handled school without that teacher... Sometimes he was a dickhead, but I could tolerate it because I knew that he didn't cuss at us intentionally. It was our fault, and we should have done something really differently. So, I kind of trusted him.

Small group teaching made close encounters between the teacher and students possible, which helped these special students trust the teacher (see also Carr, Dunlap, Horner, Koegel, 
Turnbull, Sailor, Anderson, Albin, Koegel, \& Fox, 2002; Noddings, 2005).

\section{Discussion}

\subsection{Summary of Findings}

It is a fact that not all students adjust to the general school, as beautiful as it is at the ideological level. However, everyone has the right to get same-age peers, and when it came to young prisoners, the small group presented a group of their ilk. According to young prisoners, they needed more attention and appreciation of what they did, even though their accomplishments were not as high as "others'” school achievements. They mentioned special needs assistants and assisting teachers who had been especially supportive and helpful.

Small group teaching and caring teachers in the small group environment had, therefore, represented a change toward better school satisfaction and well-being to all those 21 young prisoners who had been moved to such a group. They had been equipped with a feeling that they can complete basic education after all. The primary benefit of small group teaching was to get basic education completed. Furthermore, finding a social peer group, a caring adult, and a more tailored and flexible school work as well as getting feedback from smaller accomplishments had made small group teaching sensible. Young prisoners had, indeed, hoped that someone would have taken care of them, especially during the last school years.

In most cases, transition to small group teaching had, at least, stopped the accumulation of negative behaviors. The students' absenteeism had decreased and they had even enjoyed being at school every now and then. This progress was not stable, however, for all. In small group teaching, some of them had also learned about criminal activities and the criminal path started in this peer group, which is rather typical of juvenile delinquency. As the criminal behavior increased, school work became secondary and absenteeism started to take place. On the other hand, absenteeism was under control to the extent that not many of the young prisoners had to repeat a class. And even those who did could perform their compulsory education eventually without dropping out.

Young prisoners' first goal at school was to get to school every day, but especially get out from school finally. Learning and study success were not very significant to them. Learning as such could have been successful to many of them. Other factors had, however, interrupted their studies and eventually eroded their last wish to even complete basic education. Learning goals were not among the first priorities in their lives. In all, the young prisoners' narratives were stigmatized with strong resistance and rebellion against school practices. They were amazed and angered by the limits of time, space, routines, and power in group-based and goal-oriented school work.

Transition to small group teaching has been one concrete and clear way of helping children with problem behaviors. However, this method can also be seen stigmatizing and selective when considering the student's future. The young prisoners in this study did not see it as problematic that they were moved in a small group due to their bad behavior. Although they realized small group teaching could also have a negative influence, they considered the repetitious negative experiences of inferiority in relation to classmates in general education, 
especially in relation to the classmates coming from higher social classes, “doctors' and lawyers' kinds". Also teachers' children were considered different, as were "others who had everything fine at home and are fucking loaded with money and such". The perceived otherness in relation to children from better backgrounds was strongly manifested in young prisoners' narratives.

The experiences of inequality seemed to originate in social backgrounds and even across generations. Transition to small group teaching can include the inequality dimension but it was not seen negatively by the young prisoners. Much worse was the disrespectful encounter and treatment faced at school. In small group teaching, the young prisoners had felt they were accepted and appreciated as themselves, with their backgrounds.

Although small group teaching represented a step to a favorable direction, it still was not enough, because these children ended up in criminal paths. How could small group teaching be developed, then? The young prisoners' interviews pointed out several elements that make a successful small group teaching that can be worth focusing on. We combine the elements here as the pedagogy of preventing social exclusion (PPSE).

\subsection{The Pedagogy of Preventing Social Exclusion (PPSE)}

Based on the findings, we concluded that a pedagogy of preventing social exclusion could be based on the positive factors named by and emerging from the data collected among the young prisoners. When it comes to the special groups of students in danger of exclusion, PPSE could answer to their needs by focusing on the most salient means of support and help through establishing the sense of communality, focusing on flexible teaching methods, and caring teacherhood. When elaborating the pedagogy further, it seems that it consists of quite practical but important elements that can be the keys of positive development among students in danger of exclusion.

The teacher using PPSE is expected to teach good manners, to know students and their life situations and appreciate different life styles, to teach responsibility and awareness of one's role in society, to look persistently and actively for optional positive ways of guiding students when they have difficulties, and to teach students how to learn. Teachers also should guide students to respect and follow shared rules. Therefore, PPSE does not cover just the teaching of school subjects, but emphasizes the learning of social skills and communality as well as mutual support between classmates. The students in small group teaching have to be taught basic manners that they probably have not been taught at their homes; they need hands-on information about what is appropriate and good behavior, and why these things matter.

When it comes to learning goals, new ways of making studying meaningful should be actively searched. As the young prisoners' interviews showed, rewards should be reasonable and worth pursuing. These students do not aim at A and A+, but, for example, being able to make some coffee can be a much more functional reward. Instead of blaming and humiliating, sticking to minor mistakes, PPSE looks for the smallest accomplishments trying to figure out the strengths in students in danger of exclusion. Successes can be as little as getting at school in time or getting to school in the first place, finishing homework properly, or helping a 
classmate with a problem. As long as students get to school, although late, they are not dropping out and the school has a chance to succeed in socializing and attaching the young in society.

Providing students with a sense of success through small steps does not only increase their self-appreciation and well-being but also appreciation of school and education. The key in PPSE is the teacher's new caring way of encountering students and comprehensive familiarization of students.

\section{Conclusion}

The school should seize on children's problems more efficiently and alertly, and by using multi-professional network efficiently (see e.g., Koskela et al., 2012; Logan, 2006; Morgan, Ashbaker, \& Forbush, 1998; Openshaw, 2008). In many cases, the signs of dropping out and related exclusion processes are visible. Research has shown that factors causing problems later in life can be recognized already in childhood: such as the social status and problems of family including parents' alcohol abuse and mental problems, economic difficulties and unemployment and serious conflicts (Crijnen, Achenbach, \& Verhulst, 1997). Likewise, various difficulties at school, such as learning and behavioral problems, poor school achievements and bullying, are crucial predictors (Rescorla, Achenbach, Ivanova, Dumenci, Almqvist, Bilenberg, \& Verhulst, 2007; Sander, Sharkey, Olivarri, Tanigawa, \& Mauseth, 2010).

In this study, the young prisoners, who defined themselves as substance abusers, had skipped school constantly, because, at first, they had not felt like going to school and later on, did not care anymore. The school's task is to control absenteeism and interfere when necessary (see Dusenbury, Brannigan, Falco, \& Hansen, 2003).

Juvenile delinquency also includes the social element in youngsters' criminal behavior (Bouchard \& Spindler, 2010; Zhang, Welte, \& Wieczorek, 1999). In the United States, at least one third of young criminals are members of a gang (Yoder, Whitbeck, \& Hoyt, 2003). It is an increasing problem in, for example, China as well, which has been explained with the structural changes of society, the increase in geographical movement, and the rise in of economic insecurity (Ngai, Cheung, \& Ngai, 2007). The popularity of gang behavior has been illustrated with theories such as the theory of social control (Hirschi, 1969). The youth become members of a gang more easily if they are not integrated in their communities, quit school, and become unemployed, and if criminal activity takes place in their immediate environment (Gatti, Tremblay, Vitaro, \& McDuff, 2005; Hill, Howell, Hawkins, \& Battin-Pearson, 1999; Parente \& Mahoney, 2009; Shawn \& Donovan, 2006). This viewpoint manifests how criminal behavior and gang membership are the harmful options for lacking social connection and positive social relationships at school and at home environment.

Given these facts and the young prisoners' experiences described in this study, it seems extremely important to invest in such work in schools that makes each schoolchild feel like being a full member of the class and being accepted as he or she is. PPSE emphasizes the key elements of finding students' strengths and building on them. PPSE as introduced here is 
based on the positively-perceived factors of small group teaching: communality and peer group, flexible and functional study methods, and caring, encouraging teachers.

Even the worst-behaving students need successes and positive reinforcement; this might be the only way of showing the right direction. After all, education is supposed to prepare good citizens, teach the basics of how to manage and do well in society. If the message sent from school is that you are not good enough and your efforts do not matter, the consequences can be the saddest, as it was shown in this study. But this study also implied that if school paid holistic attention, supported children comprehensively, and noticed their backgrounds, and then offered ways of finding one's strengths, experience accomplishments, creating positive and supportive friendships instead of gang membership, and having a sense of becoming accepted and appreciated, even students in danger of exclusion could have better chances of growing into a full member of society. PPSE can function a tool to address these multidimensional issues and notice the needs of students in risk.

\section{References}

Abbott, H. P. (2008). The Cambridge introduction to narrative. Cambridge: Cambridge University Press.

Adelman, H. S., \& Taylor, R. (2006). School and community collaboration to promote a safe learning environment. The Journal of the National Association of State Boards of Education, 7(xx), 38-43.

Archambault, I., Janosz, M., Morizot, J., \& Pagani, L. (2009). Adolescent behavioral, affective, and cognitive engagement in school: relationship to dropout. Journal of School Health, 79(9), 408-415. http://dx.doi.org/10.1111/j.1746-1561.2009.00428.x

Arias, J. J., \& Walker, D. M. (2004). Additional evidence on the relationship between class size and student performance. The Journal of Economic Education, 35(4), 311-329. http://dx.doi.org/10.3200/JECE.35.4.311-329.

Atkinson, R. (2007). The life story interview as a bridge in narrative inquiry. In D. J. Clandinin (Ed.), Handbook of narrative inquiry. Mapping a methodology (pp. 224-245). Thousand Oaks, CA: Sage.

Baker, J. A. (2006). Contributions of teacher-child relationships to positive school adjustment during elementary school. Journal of School Psychology, 44(3), 211-229. http://dx.doi.org/10.1016/j.jsp.2006.02.002

Battin-Pearson, S., Newcomp, M. D., Abbott, R. D., Hill, K. G., Catalano, R. F., \& Hawkins, J. D. (2000). Predictors of early high school dropout: A test of five theories. Journal of Educational Psychology, 92(3), 568-582. http://dx.doi.org/10.1037/0022-0663.92.3.568

Blatchford, P., Russell, A., Bassett, P., Brown, P., \& Martin, C. (2007). The effect of class size on the teaching of pupils aged 7-11 years. School Effectiveness and School Improvement, 18(2), 147-172. http://dx.doi.org/10.1080/09243450601058675

Blondal, K. S., \& Adalbjarnardottir, S. (2009). Parenting practices and school dropout: A 
longitudinal study. Family Therapy, 36(3), 125-145.

Borland, M. V., Howsen, R. M., \& Trawick, M. W. (2005). An investigation of the effect of class size on student academic achievement. Education Economics, 13(1), 73-83. http://dx.doi.org/1080/0964529042000325216

Bouchard, M., \& Spindler, A. (2010). Groups, gangs, and delinquency: Does organization matter? Journal of Criminal Justice, 38(5), 921-933. http://dx.doi.org/10.1016/j.jcrimjus.2010.06.009.

Brown, T. M., \& Rodríguez, L. F. (2009). School and the co-construction of dropout. International Journal of Qualitative Studies in Education, 22(2), 221-242. http://dx.doi.org/10.1080/09518390802005570

Burr, V. (1995). An introduction to social constructionism. London: Routledge.

Busch, T., \& Kimble, C. S. (2001). Grieving children: Are we meeting the challenge? Pediatric Nursing, 27(4), 414-418.

Carr, E. G., Dunlap, G., Horner, R. H., Koegel, R. L., Turnbull, A. P., Sailor, W., Anderson, J., Albin, R. W., Koegel, L. K., \& Fox, L. (2002). Positive behavior support: Evolution of an applied science. Journal of Positive Behavior Interventions, 4(1), 4-16. http://dx.doi.org/10.1177/109830070200400102

Chapman, C., Laird, J., \& KewalRamani, A. (2010). Trends in high school dropout and completion rates in the United States: 1972-2008. Retrieved from: http://nces.ed.gov/pubsearch.

Chase, S. E. (2005). Narrative inquiry. Multiple lenses, approaches, voices. In N. K. Denzin \& Y. S. Lincoln (Eds.), The Sage handbook of qualitative research (pp. 651-679) (3rd ed.) Thousand Oaks, CA: Sage.

Chen, Q., Hughes, J. N., Liew, J., \& Kwok, O. M. (2010). Joint contributions of peer acceptance and peer academic reputation to achievement in academically at-risk children: Mediating processes. Journal of Applied Developmental Psychology, 31(6), 448-459. http://dx.doi.org/10.1016/j.appdev.2010.09.001

Christenson, S. L., \& Thurlow, M. L. (2004). School dropouts: Prevention considerations, interventions, and challenges. Current Directions in Psychological Science, 13(1), 36-39. http://dx.doi.org/10.1111/j.0963-7214.2004.01301010.x

Cortazzi, M., \& Jin, L. (2006). Asking questions, sharing stories and identity construction: Sociocultural issues in narrative research. In S. Trahar (Ed.), Narrative research on learning: Comparative and international perspectives (pp. 27-46). Oxford: Symposium Books.

Crijnen, A. A., Achenbach, T. M., \& Verhulst, F. C. (1997). Comparisons of problems reported by parents of children in 12 cultures: Total problems, externalizing, and internalizing. Journal of the American Academy of Child \& Adolescent Psychiatry, 36(9), 1269-1277. http://dx.doi.org/10.1097/00004583-199709000-00020 
Dearden, L., Emmerson, C., Frayne, C., \& Meghir, C. (2005). Education subsidies and school drop-out rates (No. 05/11). IFS Working Papers, Institute for Fiscal Studies (IFS). http://dx.doi.org/10.1920/wp.ifs.2005.0511.

Denham, A., Hatfield, S., Smethurst, N., Tan, E., \& Tribe, C. (2006). The effect of social skills interventions in primary school. Educational Psychology in Practice, 22(1), 33-51. http://dx.doi.org/10.1080/02667360500512411

Deuchar, R. (2009). Seen and heard, and then not heard: Scottish pupils' experience of democratic educational practice during the transition from primary to secondary school. Oxford Review of Education, 35(1), 23-40. http://dx.doi.org/10.1080/03054980802018871

De Wet, C. (2010). Victims of education-targeted bullying: A qualitative study. South African Journal of Education, 30(2), 189-201.

Dorman, J. (2001). Associations between classroom environment and academic efficacy. Learning Environments Research, 4(3), 243-257. http://dx.doi.org/10.1023/A:1014490922622

Dusenbury, L., Brannigan, R., Falco, M., \& Hansen, W. B. (2003). A review of research on fidelity of implementation: implications for drug abuse prevention in school settings. Health Education Research, 18(2), 237-256. http://dx.doi.org/10.1093/her/18.2.237

Dynarski, M., \& Gleason, P. (2002). How can we help? What we have learnt from recent federal dropout prevention evaluations. Journal of Education for Students Placed at Risk, 7(1), 43-69. http://dx.doi.org/10.1207/S15327671ESPR0701_4

Dzuka, J., \& Dalbert, C. (2007). Student violence against teachers: teachers' well-being and the belief in a just world. European Psychologist, 12(4), 253-260. http://dx.doi.org/10.1027/1016-9040.12.4.253

Farmer, T. W., McAuliffe Lines, M., \& Hamm, J. V. (2011). Revealing the invisible hand: The role of teachers in children's peer experiences. Journal of Applied Developmental Psychology, 32(5), 247-256. http://dx.doi.org/10.1016/j.appdev.2011.04.006

Ferri, B. A., \& Connor, D. J. (2005). Tools of exclusion: Race, disability, and (re)segregated education. Teachers College Record, 107(3), 453-474.

Fischer, C., Bol, L., Pribesh, S., \& Nunnery, J. (2013). Where is the learning in smaller learning communities? Academic press, social support for learning, and academic engagement in smaller learning community classrooms. Journal of Education for Students Placed at Risk, 18(3-4), 177-192. http://dx.doi.org/10.1080/10824669.2013.811569

Fryer-Edwards, K., Arnold, R., Baile, W., Tulsky, J., Petracca, F., \& Back, A. (2006). Reflective teaching practices: An approach to teaching communication skills in a small-group setting. Academic Medicine, 81(7), 638-644. http://dx.doi.org/10.1097/01.ACM.0000232414.43142.45

Gardner, M., \& Steinberg, L. (2005). Peer influence on risk taking, risk preference, and risky 
decision making in adolescence and adulthood: An experimental study. Developmental Psychology, 41(4), 625-635. http://dx.doi.org/10.1037/0012-1649.41.4.625

Garrison, A. (2006). "I missed the bus": School grade transition, the Wilmington truancy center, and reasons youth don't go to school. Youth Violence and Juvenile Justice, 4(2), 204-212. http://dx.doi.org/10.1177/1541204006286318

Gatti, U., Tremblay, R., Vitaro, F., \& McDuff, P. (2005). Youth gangs, delinquency and drug use: A test of the selection, facilitation, and enhancement hypotheses. Journal of Child Psychology and Psychiatry and Allied Disciplines, 46(11), 1178-1190. http://dx.doi.org/10.1111/j.1469-7610.2005.00423.x

Gergen, K. J. (2009). An invitation to social construction (2nd ed.) London: Sage.

Hill, K. G., Howell, J. C., Hawkins, J. D., \& Battin-Pearson, S. R. (1999). Childhood risk factors for adolescent gang membership: result from the Seattle social development project. Journal of Research in Crime and Delinquency, 36(3), 300-322. http://dx.doi.org/10.1177/0022427899036003003

Hirschi, T. (1969). Causes of delinquency. Berkeley, CA: University of California Press.

Holland, J. (2008). How schools can support children who experience loss and death. British Journal of Guidance \& Counselling, 36(4), 411-424. http://dx.doi.org/10.1080/03069880802364569

Horgan, G. (2009). “That child is smart because he’s rich”: The impact of poverty on young children's experiences of school. International Journal of Inclusive Education, 13(4), 359-376. http://dx.doi.org/10.1080/13603110802707779

Hughes, J. N., \& Chen, Q. (2011). Reciprocal effects of student-teacher and student-peer relatedness: Effects on academic self-efficacy. Journal of applied Developmental Psychology, 32(5), 278-287. http://dx.doi.org/10.1016/j.appdev.2010.03.005

Jimerson, S. G., Egeland, B., Sroufe, L. A., \& Carlson, B. (2000). A prospective longitudinal study of high school dropouts examining multiple predictors across development. Journal of School Psychology, 38, 525-549. http://dx.doi.org/10.1016/S0022-4405(00)00051-0

Jonker, E. F. (2006). School hurts: Refrains of hurt and hopelessness in stories about dropping out at a vocational school for care work. Journal of Education and Work, 19(2), 121-140. http://dx.doi.org/10.1080/13639080600667988

Knesting, K., \& Waldron, N. (2006). Willing to play the game: How at-risk students persist in school. Psychology in the Schools, 43(5), 599-611. http://dx.doi.org/10.1002/pits.20174

Koskela, T., Määttä, K., \& Uusiautti, S. (2012). Pupil welfare in Finnish schools - communal or falling apart? Early Child Development and Care, 183(9), 1311-1323. http://dx.doi.org/10.1080/03004430.2012.725049

Kuronen, I. (2010). Peruskoulusta elämänkouluun. Ammatillisesta koulutuksesta syrjäytymisvaarassa olevien nuorten aikuisten tarinoita peruskoulusuhteesta ja 
elämänkulusta peruskoulun jälkeen [From basic education to the school of life. Narratives of young adults in danger of exclusion from vocational education about relationship with basic education and life after basic education]. Jyväskylä: University of Jyväskylä.

Kvale, S. (2002). The social construction of validity. In N. K. Denzin \& Y. S. Lincoln (Eds.), The qualitative inquiry reader (pp. 299-325). Thousand Oaks, CA: Sage.

Kvale, S. (2007). Doing interviews. London: Sage.

Lareau, A., \& McNamara Horvat, E. (1999). Moments of social inclusion and exclusion race, class, and cultural capital in family-school relationships. Sociology of Education, 72(1), 37-53.

Lieblich, A., Tuval-Mashiach, R., \& Zilber, T. (1998). Narrative research reading, analysis and interpretation. London: Sage.

Liew, J., Chen, Q., \& Hughes, J. N. (2010). Child effortful control, teacher-student relationships, and achievement in academically at-risk children: Additive and interactive effects. Early Childhood Research Quarterly, 25(1), 51-64. doi:10.1016/j.ecresq.2009.07.005

Logan, A. (2006). The role of the special needs assistant supporting pupils with special educational needs in Irish mainstream primary schools. Support for Learning, 21(2), 92-99.

Miech, R., Caspi, A., Moffitt, T., Wright, B., \& Silva, P. (1999). Low socioeconomic status and mental disorders: A longitudinal study of selection and causation during young adulthood. American Journal of Sociology, 104(4), 1096-1131.

Ministry of Education and Culture. (2012). Perusopetuksen laatukriteerit. Perusopetuksen, perusopetuksen aamu- ja iltapäivätoiminnan sekä koulun kerhotoiminnan laatukriteerit [Quality criteria for basic education. Quality criteria for basic education, morning and afternoon activities of basic education and school club activies]. Helsinki: Ministry of Education and Culture.

Ministry of Education and Culture. (2014). Opetusryhmien tila Suomessa. Selvitys eduskunnan sivistysvaliokunnalle esi- ja perusopetuksen opetusryhmien nykytilasta [The situation of teaching groups in Finland. Report of the current situation of pre-primary and basic education to the Committee for Education and Culture]. Helsinki: Ministry of Education and Culture.

Morgan, J., Ashbaker, B., \& Forbush, D. (1998). Strengthening the teaching team: Teachers and paraprofessionals learning together. Support for Learning, 13(3), 115-117.

Ngai, N., Cheung, C., \& Ngai, S. S. (2007). Cognitive and social influences on gang involvement among delinquents in three Chinese city. Adolescence - San Diego, 42(166), 381-403.

Noddings, N. (2005). The challenge to care in schools: an alternative approach to education. New York, NY: Columbia University.

Openshaw, L. (2008). Social work in school. Principles and practice. New York, NY: The 
Guilford Press.

Orfield, G., Losen, D., Wald, J., \& Swanson. (2004). Losing our future: How minority youth are being left behind by the graduation rate crisis. Cambridge, MA: The Civil Rights Project at Harvard University.

Parente, M. E., \& Mahoney, J. L. (2009). Residential mobility and exposure to neighborhood crime: risks for young children's aggression. Journal of Community Psychology, 37(5), 559-578. http://dx.doi.org/10.1002/jcop.20314

Pedder, D. (2006). Are small classes better? Understanding relationships between class size, classroom processes and pupils' learning. Oxford Review of Education, 3(2), 213-234. http://dx.doi.org/10.1080/03054980600645396.

Pirttiniemi, J. (2005). Perusopetuksen ja toisen asteen nivelvaiheen kehittäminen [Development of the transition phase from basic education and upper secondary education]. In P. Koivula (Ed.), Selviytymisen polkuja. Opetusjärjestelyt oppilaan tukena [Paths of survival. Teaching arrangements as students’ support] (pp. 32-39). Helsinki: National Board of Education.

Polkinghorne, D. E. (1995). Narrative knowing and the human sciences. Albany, NY: State University of New York Press.

Reich, R. B. (2006). Why the rich are getting richer and the poor, poorer? In H. Lauder, P. Brown, J. Dillabough, \& A. H. Halsey (Eds.), Education, globalization \& social change (pp. 308-316). Oxford: Oxford University Press.

Rescorla, L., Achenbach, T., Ivanova, M. Y., Dumenci, L., Almqvist, F., Bilenberg, N., \& Verhulst, F. (2007). Behavioral and emotional problems reported by parents of children ages 6 to 16 in 31 societies. Journal of Emotional and behavioral Disorders, 15(3), 130-142. http://dx.doi.org/10.1177/10634266070150030101

Riessman, C. K. (2008). Narrative methods for the human sciences. Los Angeles, CA: Sage.

Rudasill, K. M. (2011). Child temperament, teacher-child interactions, and teacher-child relationships: A longitudinal investigation from first to third grade. Early Childhood Research Quarterly, 26(2), 147-156. http://dx.doi.org/10.1016/j.ecresq.2010.07.002

Sander, J. B., Sharkey, J. D., Olivarri, R., Tanigawa, D. A., \& Mauseth, T. (2010). A qualitative study of juvenile offenders, student engagement, and interpersonal relationships: Implications for research directions and preventionist approaches. Journal of Educational and Psychological Consultation, 20(4), 288-315. doi:10.1080/10474412.2010.522878

Sarras, R. (2011). Klassestørrelse og lerinsgutbytte - hva viser forskningen? Temanotat 3/2011. Oslo: Utdanningsforbundet. Retrieved from: http://www.utdanningsforbundet.no/upload/Publikasjoner/Temanotat/Temanotat\%202011/Te manotat_2011_03.pdf

Shannon, G. S., \& Bylsma, P. (2003). Helping students finish school: Why students drop out 
and how to help them graduate. Olympia, WA: Office of Superintendent of Public Instruction.

Sharabi, A., Levi, U., \& Margalit, M. (2012). Children's loneliness, sense of coherence, family climate, and hope: Developmental risk and protective factors. The Journal of Psychology, 146(1-2), 61-83. http://dx.doi.org/10.1080/00223980.2011.568987

Swanson, J., Valiente, C., Lemery - Chalfant, K., Bradley, R. H., \& Eggum - Wilkens, N. D. (2014). Longitudinal relations among parents' reactions to children's negative emotions, effortful control, and math achievement in early elementary school. Child Development, EarlyView. http://dx.doi.org/10.1111/cdev.12260

Shawn, M. H., \& Donovan, J. E. (2006). Alcohol and violence: comparison of the psychosocial correlates of adolescent involvement in alcohol-related physical fighting versus other physical fighting. Addictive Behaviors, 31(11), 2014-2029.

Split, J. L., Hughes, J. N., Wu, J. Y., \& Kwok, O. M. (2012). Dynamics of teacher-student relationships: Stability and change across elementary school and the influence on children's academic success. Child Development, 83(4), 1180-1195. http://dx.doi.org/10.1111/j.1467-8624.2012.01761.x

Staff, J., \& Kreager, D. A. (2008). Too cool for school? Violence, peer status and high school dropout. Social Forces, 87(1), 445-471. http://dx.doi.org/10.1353/sof.0.0068

Sutherland, A. (2011). The relationship between school and youth offending. Social Policy Journal of New Zealand, 37, 51-69.

Teodorovic, J. (2012). Student background factors influencing student achievement in Serbia. Educational Studies, 38(1), 89-110. http://dx.doi.org/10.1080/03055698.2011.567027

Terry, M. (2008). The effects that family members and peers have on students' decisions to drop out of school. Educational Research Quarterly, 31(3), 25-38.

Vitaro, F., Larocque, D., Janosz, M., \& Tremblay, R. E. (2001). Negative social experiences and dropping out of school. Educational Psychology, 21(4), 401-415. http://dx.doi.org/10.1080/01443410120090795

Watson, S. (2006). The stories people tell: teaching narrative research methodology in New Zealand. In S. Trahar (Ed.), Narrative research on learning: comparative and international perspectives (pp. 61-76). Oxford: Symposium Books.

Weerman, F. M. (2003). Co-offending as social exchange: explaining characteristics of co-offending. The British Journal of Criminology, 43(2), 398-416. http://dx.doi.org/10.1093/bjc/43.2.398

Wells, K. (2011). Narrative inquiry. Oxford: Oxford University Press.

Wilkins, J. (2008). School characteristics that influence student attendance: experiences of students in a school avoidance program. The High School Journal, 91(2), 12-24. http://dx.doi.org/10.1353/hsj.2008.0005 


\section{Macrothink}

Journal of Studies in Education

ISSN 2162-6952

2014, Vol. 4, No. 4

Williford, A. P., Maier, M. F., Downer, J. T., Pianta, R. C., \& Howes, C. (2013). Understanding how children's engagement and teachers' interactions combine to predict school readiness. Journal of Applied Developmental Psychology, 34(6), 299-309. http://dx.doi.org/10.1016/j.appdev.2013.05.002

Wilson, V., Malcolm, H., Edward, S., \& Davidson, J. (2008). "Bunking off”: the impact of truancy on pupils and teachers. British Educational Research Journal, 34(1), 1-17. http://dx.doi.org/10.1080/01411920701492191

Yoder, K. A., Whitbeck, L. B. \& Hoyt, O. R. (2003). Gang involvement and membership among homeless and runaway youth. Youth \& Society, 34(4), 441-467. http://dx.doi.org/10.1177/0044118X03034004003

Zhang, L., Welte, J. W., \& Wieczorek, W. F. (1999). Youth gangs, drug use, and delinquency. Journal of Criminal Justice, 27(2), 101-109. http://dx.doi.org/10.1016/S0047-2352(98)00032-4

Äärelä, T. (2012). “Aika palijon vaikuttaa minkälainen ilime opettajalla on naamalla” Nuoret vangit kertovat peruskouluajoistaan ["It means quite a lot what kind of look a teacher has” Young prisoners talking about their experiences at a comprehensive school]. (PhD Diss., University of Lapland, Rovaniemi.)

Äärelä, T., Uusiautti, S., \& Määttä, K. (2014). “The teacher should not just boss around all the time". Good teacherhood in the light of young prisoners' experiences. Problems of Education in the 21st Century, 60(60), 10-22.

\section{Copyright Disclaimer}

Copyright for this article is retained by the author(s), with first publication rights granted to the journal.

This is an open-access article distributed under the terms and conditions of the Creative Commons Attribution license (http://creativecommons.org/licenses/by/3.0/). 